\title{
Healing and coping with life within challenges of spiritual insecurity: Juxtaposed consideration of Christ's sinlessness and African ancestors in pastoral guidance
}

\begin{tabular}{|c|c|}
\hline \multicolumn{2}{|c|}{$\begin{array}{l}\text { Author: } \\
\text { Vhumani Magezi }{ }^{1} \\
\text { Christopher Magezi }\end{array}$} \\
\hline \multicolumn{2}{|c|}{$\begin{array}{l}\text { Affiliation: } \\
{ }^{1} \text { Faculty of Humanities, } \\
\text { School of Basic Sciences, } \\
\text { North-West University, } \\
\text { Vaal Triangle Campus, } \\
\text { South Africa }\end{array}$} \\
\hline \multicolumn{2}{|c|}{$\begin{array}{l}\text { Corresponding author: } \\
\text { Vhumani Magezi, } \\
\text { 12403741@nwu.ac.za }\end{array}$} \\
\hline \multicolumn{2}{|c|}{$\begin{array}{l}\text { Dates: } \\
\text { Received: } 05 \text { Oct. } 2016 \\
\text { Accepted: } 09 \text { Feb. } 2017 \\
\text { Published: } 03 \text { Apr. } 2017\end{array}$} \\
\hline \multicolumn{2}{|c|}{$\begin{array}{l}\text { How to cite this article: } \\
\text { Magezi, V. \& Magezi, C., } \\
\text { 2017, 'Healing and coping } \\
\text { with life within challenges of } \\
\text { spiritual insecurity: } \\
\text { Juxtaposed consideration of } \\
\text { Christ's sinlessness and } \\
\text { African ancestors in pastoral } \\
\text { guidance', HTS Teologiese } \\
\text { Studies/Theological Studies } \\
\text { 73(3), a4333. https://doi. } \\
\text { org/10.4102/hts.v73i3.4333 }\end{array}$} \\
\hline \multicolumn{2}{|c|}{$\begin{array}{l}\text { Copyright: } \\
\text { (C) 2017. The Authors. } \\
\text { Licensee: AOSIS. This w } \\
\text { is licensed under the } \\
\text { Creative Commons } \\
\text { Attribution License. }\end{array}$} \\
\hline \multicolumn{2}{|l|}{ Read online: } \\
\hline 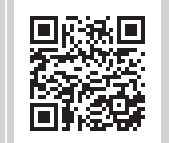 & $\begin{array}{l}\text { Scan this QR } \\
\text { code with your } \\
\text { smart phone or } \\
\text { mobile device } \\
\text { to read online. }\end{array}$ \\
\hline
\end{tabular}

Spiritual insecurity among African Christians is a huge challenge. The insecurity among other things arises from African people's former traditional African ancestral world view of ancestral veneration. The ancestors promote or hinder African Christians' reliance on Christ because they have presupposedly acquired the supernatural power that enables them to provide diagnoses and solutions to life challenges. The inherent problem in the ancestral world view, however, is that the ancestors are both respected and feared by their descendants because they can either bless or harm depending on the state of the relationship between the surviving human beings and the ancestors. The basis of the unpredictable influence of ancestors lies in the fact that they (ancestors) are considered as human beings who carry their human qualities to the spiritual world. In light of this situation, one constructive approach that can be advanced to address the challenges of African Christians' spiritual insecurity is a proper understanding of Christ as a sinless representative of humanity. This approach maintains that healing and coping with life within the challenge of African spirituality in the context of threatening life issues can be addressed by an appropriate understanding of Christ's sinlessness. The article argues for the foundational status of Christ as a sinless representative of humanity as the controlling framework. In doing so, Christ's sinlessness and the sinfulness of natural ancestors are juxtaposed to compare the two ontologies in order to draw some pastoral guidelines for African Christians. This approach pays close attention to the factors and mindset that sustain people who adhere to ancestral worship and assess them through a lens of Christology focusing on Christ's sinlessness as an exemplary doctrine.

\section{Introduction and background}

There is perceived spiritual insecurity in traditional African religion that arises from the traditional African world view of spiritual powers such as the Supreme Being, Lesser divinities and angry ancestral spirits (Banda 2005:2-6; Kok 2005:95-101; Kunhiyop 2012:59; Michael 2013:99; Nurnberger 2007:8-42). In traditional African religion, protection from spiritual threats of this kind is obtained from charms, ancestors and traditional medical practitioners such as diviners and ancestors (Mbiti 1989:165-174; Nakah 2006:32; Sogolo 1991:177-182). This spiritual insecurity persists among Africans who then convert to Christianity. At conversion, African Christians are taught to relinquish reliance on these traditional spiritual powers and to trust only in Jesus Christ for their spiritual protection. However, in times of crisis such as when they face sickness, death or inexplicable life situations, some African Christians revert to their previously abandoned traditional forms of security, while continuing to believe in Christ as offering eternal salvation (cf. Banda 2005:2-6; Kok 2005:95-101; Kunhiyop 2012:59; Michael 2013:99; Nurnberger 2007:8-42).

Notably, the problem of spiritual insecurity in African Christianity is inherent within the interrelationship between how people think and relate to reality. ${ }^{1}$ Thus, the challenge to develop a framework that is appropriate and consistent with biblical teaching (appropriate understanding of God of the Bible who saves us) is inevitable (faith-seeking understanding). This understanding should be complemented by appropriate action (faith-seeking action). The question is why African Christians revert to their abandoned forms of addressing their spiritual security while they continue

\footnotetext{
1.For a detailed understanding of how people think and relate to reality, one should visit Benn (2000:11), Naugle (2002:151-160) Hesselgrave (1991:199-102) and Kraft's (1999:384-386) articulation of the definition of a world view. These scholars concur that a Hesselgrave (1991:199-102) and Kraft's (1999:384-386) articulation of the definition of a world view. These scholars concur that a
world view denotes people's inbuilt framework for perceiving reality, which governs their behaviours and actions. That is, a world view is people's perception of reality or thinking about the world, without limiting the concept (of a world view) to either pure reasoning or any form of scientific truth. This is because, even though people's world view can be described as counterfeit, irrational or unscientific, still their conceptualisation of reality is central in determining their behaviours and actions in life.
} 
to hold on to Christ for security. Part of the answer lies in the African people's worldview of health, life and sickness (Okorocha 1994:62-91; cf. Banda 2005). At the core of traditional African world views of health, life and sickness, there are natural ancestors who provide diagnoses and solutions to the problems, therefore resulting in Africans' relying on them as providing a comprehensive way of responding to life challenges (Triebel 2002). The ancestors and diviners work synergistically to provide diagnoses and recommend practical curative solutions at both spiritual and physical levels.

On the contrary, Christianity seems to offer abstract and impractical solutions to life's challenges. The impracticality arises from a number of reasons. Firstly, Christianity tends to focus on a futuristic perspective of life as if it has nothing to offer in the current life. Secondly, Christianity offers probabilities that are not concrete to addressing problems through the formula 'if it's God's will', which could be interpreted as uncertainty. Thirdly, the conception of healing within pastoral ministry, particularly within the Reformed tradition, tends to be philosophical (and cognitive) rather than practical and curative as done by ancestors. This portrayal of Christ and Christianity almost entirely as a cognitive concept that is divorced from engagement with practical spiritual realities of life makes Christianity an abstract concept. This has resulted in viewing Christ and Christianity as just reciting the correct doctrine without paying attention to practical implications, particularly the engagement with spiritual forces. This therefore has caused Christ to be viewed as very distant and uninvolved in African believers' lives at this Christian interim period. Regrettably, this approach severely weakens the fundamental aspect of Christianity and Christian doctrines, predominantly when one views his or her position in Christ as a saved human being. This overlooks the reality of Christians' union with Christ as foundational and fundamental principles for coping with life such as peace, security, confidence and reliance.

The question that arises from the above-mentioned discussion is: how can African Christians understand their position in Christ as secure within the context of African spirituality, with particular focus on ancestors as the central belief within traditional African religion and spirituality (Triebel 2002:193). African ancestorship arguably occupies the most central place that either promotes or hinders African Christians' reliance on Christ. One fundamental response to this challenge is a proper understanding of Christ as a sinless representative of humanity and ensuing implications of that doctrine to practical life, particularly in challenging African spiritual contexts. In view of the above-stated challenge, healing and coping with life with the challenge of African spirituality in the context of threatening life issues could be addressed by an appropriate understanding of Christ's sinlessness and the ensuing implication of this doctrine juxtaposed with African ancestors. Juxtaposition entails placing aspects or actions side by side to compare and contract them. Such an approach pays close attention to factors and mindset that sustains adherents to African ancestral worship and assess them through a thorough lens of appropriate and constructive Christology focusing on Christ's sinlessness as an exemplary doctrine. This consideration merges doctrinal articulation of Christ as the sinless representative of humanity and its implications to informing practical ministry and life of people who feel insecure in Christ. In articulating the biblical-theological foundational status of the doctrine of Christ as a sinless representative of humanity, Torrance's conception will be used as a controlling framework but supported by other theologians. ${ }^{2}$

In order to achieve the objective of this article, the initial section will focus on the spiritual insecurity arising from traditional African ancestral world view of ancestral veneration. This will be followed by an exposition of the biblical-theological foundational status of the doctrine of Christ as a sinless representative of humanity using Torrance as a representative theologian in dialogue with other theologians. Once this is done, these frameworks will be juxtaposed to draw the distinction of Christ and ancestors. In doing so, lessons for practical life that will inform and guide Christians to cope with life in their challenges of spiritual insecurity will be drawn.

\section{Africans' spiritual insecurity arising from their belief in traditional African ancestors as the centre of African religion}

\section{Establishing the common African world view or views}

A considerable number of African theologians (Imasogie 1983:53-54; Ishola 2002:46; Light 2010:98; Lugira 2009:48-102; Mashau 2009:117; Mbiti 1989:76; ${ }^{3}$ Turaki 2006:86; Wethmar 2006:249-250) affirm the difficulty of speaking of a unitary African world view or views because there are certain antithetical beliefs within African cultures. In stating this, these theologians concur that there are salient beliefs in African cultures, even though their expression varies from culture to culture. In delineating the divergences and convergences within the traditional African world view, Ishola (2002) maintains that:

the plurality of their expression [African beliefs] is due to over one thousand ethnic language groups, each with its own tradition,

2.Torrance's conception of Christ as a sinless representative of humanity is used as a controlling framework because he grounded his ine of humanity is used as from doctrine in the Trintarian doctrine of God. In moving from his Trinitarian doctrine of God to the incarnational mystery of God in and through Christ, Torrance maintained that Jesus Christ was fully God and man (Torrance 1996:18). In doing this, Torrance (2008:87-104) develops a biblical-theological foundational status of the need of a sinless saviour who truly identifies with all humankind in order to take up the punishment for human sin. Thus after underscoring the biblical-theological foundational status of Christ as the sinless representative of humanity, Torrance argues that the sinless saviour is Jesus Christ, the very God himself who assumed our human mode of existence and lived a perfect life in obedience to the Fathe until to the point of death at the cross, so that he can gather humankind back into eternal fellowship with God (Torrance 1992:66; 2008:73). With this aforementioned understanding Kettler (1991) contends that Torrance is: one contemporary theologian who has repeatedly in his writings brought up the significance of the theologian who has repeatedly in his writings brought up the significance of the vicarious humanity of Christ for salvation. This is a humanity which becomes the basis for a renewed and restored humanity. Certainly such an approach holds
promise to help us in our search for the reality of salvation. (p. 121)

3.Mbiti (1989:76) supports that in Africans' belief in spiritual powers, 'obviously there are local differences, but the pattern is fairly uniform throughout the traditional environment'. 
yet with uniformity in the various people's understanding of the nature of the world, the nature of human beings and their place in the world, and the nature of evil. (p. 46)

Mashau (2009) corresponds with Ishola when he extends the list of the common African elemental beliefs by positing that:

the commonalities include, among others, belief in a transcendent God, a spiritual world, ancestral spirits, a hierarchy of powers, the notion of cosmic good and African communality, and the use of spiritual powers for good or bad. (p. 117)

However, within the unvarying beliefs of traditional African cultures is the foundational world view of the interconnection between the spiritual and physical worlds (Dyrness 1990:44; Louw 2002:72; Lugira 2009:48; Mbiti 1989:74-85; Turaki 2006:34). Mbiti (1989) encapsulates the interconnection between the physical and the spiritual worlds in the statement that:

the spiritual universe is united with the physical, and that these two intermingle and dovetail into each other so much that it is not easy, or even necessary, at times to draw the distinction or separate them. (p. 74)

In this way, various African cultures recognise that the spirit world is inhabited by many spiritual powers, which are in a hierarchical relationship with one another, acting capriciously as an unpredictable influence of good and evil in the lives of Africans (Imasogie 1983:53-54; Light 2010:99-109; Lugira 2009:36-63; Mashau 2009:117; Mbiti 1989:77-80; Turaki 2006:54-66). In concurrence with some African theologians and scholars, Turaki (2006) depicts the multiplicity of spiritual powers and their hierarchy, by maintaining that:

African theologians and scholars speak about the transcendence of God, the Supreme Being, and claim that the space between God and human beings is filled with a hierarchy of gods, divinities and spirits who are sometimes called the intermediaries. (p. 61)

In this way, although there are divergences in Africans' belief in spiritual powers, there are still convergences, which enable one to expound on the nature of African spirituality (i.e. the belief in spiritual powers) as a significant African phenomenon. Hence, in order to describe the spiritual insecurity of Africans arising from their ancestral world view, the following sections provide an overview description of the nature of traditional African ancestral world views in view of 'the basic pattern and principles' as the basis of this religious phenomenon (Wethmar 2006:250).

\section{Africans' spiritual insecurity because of the ancestors or the living dead: the centre of traditional African religion and responsive Christianity}

In Mbiti (1989:78) and Igba's (2013:28) view, there is no misconception in traditional African belief concerning the position of the 'spirits and the living dead (ancestors)' in their relationship to God. African people believe that 'spirits are the destiny of man and beyond them is God. Societies that recognise divinities regard them as a further group in the ontological hierarchy between spirits and God' (Mbiti 1989:78).

On the one hand, the spirits are the deceased people, who are not remembered within their clans, tribes or families (Mbiti 1989:83-84; Reed \& Mtukwa 2010:148-149; Salala 1998:133). These spirits are ever-present, although Africans are not cognisant of the specific location where they are or what they are doing (Mbiti 1989:83-84; Salala 1998:133). Nevertheless, all these spirits are potentially malicious because they can possess people and inflict all kinds of suffering (Mbiti 1989:80-81; Nurnberger 2007:10). In this regard, human beings need to be protected from them (Ibid). Therefore, people are safeguarded from these malicious spirits and ghosts through the use of traditional medicines such as 'amulets on their necks and ropes tied to their hands', which are offered by traditional African practitioners, that is diviners (Imasogie 1983:63; Mashau 2009:119-120). However, regardless of the protection which people can obtain from traditional African practitioners, Africans are continuously afraid of this category of spiritual powers (Mbiti 1989:80-81).

On the other hand, the ancestors are those blood-related members of the family, clan or tribe who have lived an outstanding life during their lifetimes and who have presupposedly acquired supernatural powers after death, which enables them to function as both guardians and protectors of their living descendants (cf. Bediako 2004:23; Lugira 2009:48-50; Nyamiti 2006:3; Oladosu 2012:160-161). In the traditional African world view, the ancestors are the most respected and feared spiritual powers (Dyrness 1990:48; Oladosu 2012:161). Therefore, ancestors are believed by Africans to be a dominant category among the spiritual powers (Dyrness 1990:48; Reed \& Mtukwa 2010:148; Triebel 2002:193). In Dyrness (1990:48) and Mbiti's (1989:82) view, the ancestors are believed to be the dominant spiritual category because they are the closest spiritual powers to living people. Here, Mbiti and Dyrness compare the closeness of ancestral spirits with other spiritual powers to humanity (Dyrness 1990:48; Mbiti 1989:82). Mbiti (1989) puts it thus:

$[T]$ he living-dead are therefore the closest link between men and God: they know the needs of men, they have recently been here with men, and at the same time they have full access to the channel of communicating with God directly or according to some societies, indirectly through their own fore-bearers. (p. 82)

This implies that, in traditional African belief, the ancestors are present with the living, and living people rely on them for their prosperity in life (Triebel 2002:187). Oladosu (2012) puts it this way:

$[T]$ he position and function attached to the concept of ancestral veneration among the Africans identifies their community setting as a continuing unit. This continuity shows influence between the members still here on earth and those that are in the world beyond as the ancestors. (p. 161)

However, the problem which has arisen in ancestral belief is that, although the ancestors are respected, they are nevertheless feared by the living (Ashforth 2005:208-209; 
Dyrness 1990:48, 50; Oladosu 2012:161-162; Triebel 2002:190). That is, although in the preceding paragraph, the ancestors are regarded as protectors and guardians of the living, they can still bring curses upon living people in the form of 'suffering, instability, poverty, misfortune, sickness and even death' (Dyrness 1990:48; Mbiti 1989:83; Triebel 2002:192). In this instance, the ancestors are constantly watching over the living, but any human deviance from the inherited traditions' incurs curses, while the opposite (i.e. compliance with traditions) brings blessings to the living (Nurnberger 2007:66). Such inherited traditions include Africans' taking care 'to follow the proper practices and customs, especially regarding the burial or other means of disposal of dead bodies', as well as making 'libation and food offerings' to ancestors (Mbiti 1989:83).

Interestingly, Ashforth attempts to substantiate the ancestors' unpredictability by locating the origin of their capacity for causing good and evil in their flawed character (Ashforth 2005:209). He argues that they 'are still human in origin and take with them their human characteristics into the otherworld' (Ashforth 2005). Therefore:

if the ancestors carry into the afterlife the same limitations and negative human qualities they had as living members of families - absent, abusive, jealous, unreliable, tyrannical or even just plain evil - then their descendants are sorely in need of other spiritual powers to guard their security and prosperity. (p. 209)

If this is true, one could contend that the ancestors foster real spiritual insecurity within Africans. However, regardless of some African people's spiritual insecurity arising from the unpredictable behaviour of the ancestors, Triebel (2002) asserts the centrality of ancestors in African traditional beliefs, as he concludes that:

Because the ancestors cause misfortune on the one hand and because on the other hand only they can grant fortune, wellbeing, life, and a good living - that is, fullness of life - they alone are venerated. Therefore this cult is really the central aspect, the centre of African religion. (p. 193)

The possible spiritual insecurity of African Christians as a result of the capriciousness of the ancestors discussed above anticipates a Christ who addresses terrors and fears which emanate from the traditional African ancestral world view. African Christians expect a Christ who reigns over the aforementioned 'natural world of divinities, spirits and evil forces' (Hood 1990:150). In his classic essay which fleshes out the meaning of salvation from an African perspective, Okorocha (1994:62) agrees with Hood in arguing that African Christians expect Christianity will safeguard them from the invisible powers which threaten their well-being. That is, many African converts are haunted by 'an overriding concern for spiritual power from a mighty God to overcome all enemies and evils that threaten human life and vitality' (Turner, as quoted by Okorocha 1994:62). With this granted, one can argue that the search for salvation:

$[I] \mathrm{s}$ the putative force behind African conversion to Christianity, it then means that that same factor will determine both their allegiance to, and continuity in Christianity, as well as the shape and meaning of Christianity in Africa. (Okorocha 1994:91)

Banda (2005:24) supports Okorocha's point in his clear affirmation that in the African perception of attaining a stable life, secured from the attacks of the witches and other such evil forces, religion is an absolute necessity'.

\section{The Biblical-theological foundational status of Christ as a sinless representative of humanity}

\section{In overview: The vicarious humanity of Jesus Christ in Torrance's incarnational Christological theology}

In agreement with Calvin (1960:143) and Barth (1960:402403), Torrance (1995:131; 1996:15) acknowledges that evangelical theology is grounded in the Christian doctrine of the Trinity. The doctrine of the Trinity affirms that God is one being, yet three distinctive persons, namely, Father, Son and Holy Spirit (Torrance 1995:131; 1996:15). Torrance's (1992:59-60) doctrine of the Trinity is interrelated with the doctrine of the incarnation.

In articulating the relationship between the doctrine of the Trinity and incarnation, Torrance (1992:59-60) opposed the Greek cosmological dualism, which drives a wedge between God and his creation. In Torrance's view, this disjunction between God and his creation causes Christians to pose some serious questions concerning the actuality of the fundamental Christian doctrine of the incarnation, hence Christology. Normally, these questions will result in Christians diminishing the adequacy of Christ's salvation in their existential challenges. The successive questions frequently asked by Christians concerning the divinity of Christ are: 'Will God really turn out to be what we believe him to be in Jesus Christ? Is God really like Jesus?' (Torrance 1992:59). In Torrance's (1992:59) perspective, many people often pose these aforementioned questions in moments of lifethreatening crises, such as death and sickness. It is at this moment of life-threatening crisis that Christians struggle to connect the relationship between Jesus Christ and God in their Christian faith (Torrance 1992:59). Hence, in underscoring the foundational status of the doctrine of incarnation from Scripture, Torrance (1996) argues that the incarnation:

constitutes the one actual source and the one controlling centre of the Christian doctrine of God, for he who became man in Jesus Christ in order to be our Saviour is identical in Being and Act with God the Father. (p. 18)

Once the movement of the eternal Son of God within space and time is appropriately understood, Torrance (2008:231) delineates the nature of the vicarious humanity of Christ as the representative of all humanity in relation to our salvation. Torrance (2008:84, 230-232; 2009:1xxii) understands that in the incarnation, there is a once and for all solidarity between 'Christ and all mankind'; therefore, the incarnational human nature of the divine Logos identifies with all people. 
Torrance utilised the two inseparable Greek patristic theological concepts, ${ }^{4}$ namely, anhypostatic and enhypostatic union (Torrance 2008:230, 2009:lxxii-lxxiii). These Greek theological concepts determine Torrance's (2008:233) doctrine of the vicarious humanity of Christ, hence his soteriological Christology. Concerning the anhypostatic union, Torrance (2008:84, 229; 2009:1xxiii) agrees with Barth (1958:49) and Moltmann (1974:231) that this concept asserts the negative, i.e. that the general or common human nature of Jesus Christ has no independent grounding. The concept of enhypostatic union affirms the positive that in the incarnation the human nature of Christ is grounded in the eternal person of the divine Logos, which implies that the human nature of Christ acquires real existence and stability in the existence of God (Torrance 2008:84, 230; cf. Barth 1958:49). However, regarding the stability of human nature, anhypostasis is the logically prior concept in that it recognises that Jesus human nature does not have an alternative centre for grounding and expression, other than its enhypostatic grounding in the person of the divine Logos.

Karl Barth (1958:49) conceives the potential objection that is associated with the enhypostatic concept, especially in its relationship to the doctrine of the vicarious humanity of Christ, hence Christology. He stated that the concept of enhypostastic union seems to deny the actual humanity of Christ (docetism), if not understood properly (Barth 1958:49). Nonetheless, Torrance's explanation of the concept of enhypostatic union is cognisant of the previously mentioned challenge, because he qualified what he means and does not mean by his use of the enhypostastic concept. That is, by employing the concept of enhypostatic union to the vicarious humanity of Christ, Torrance (2008:230) does not mean that '... in the incarnation there was no particular individual called Jesus existing as a particular human being, with a rational human mind and will and soul'. Instead, Torrance (2008:230) believes that Jesus was a true human being, who possessed a full 'human mind and human soul and human will' in his 'hypostatic union with divine life'. Given this, in the hypostatic union of the Son of God with man in the incarnation, all human beings (including Africans) are confronted with the reality that in Christ's death, resurrection and ascension, God acted within the depths of himself and human existence to save all mankind from sin and all its consequences, including death and the negative impact of the invisible forces to humanity (Torrance 1995:4, 155, 175; 1996:203204, 224-233, emphasis added).

The above-mentioned reality of Christ's salvation in all aspects of believers' lives commences as they are eternally united to and participate in the vicarious humanity of Christ through faith in Him and His redemptive work (Torrance 1995:4-5; 2009:213-235). This eternal union and participation in the vicarious humanity of Christ is a result of the work of the Holy Spirit (cf. Jn 3:5 and Rm 8:15) in uniting us to Christ ${ }^{5}$

4.Anhypostasis and enhypostasis are the two qualifications that need to be made about the relation of the humanity of Christ to his divine person.

5.The activity of the Holy Spirit in the economy of salvation (for humanity) is related 'to the atoning substitution in the life, death and resurrection of Jesus Christ' (Torrance 1996:238)
(Torrance 1992:110; 1996:249-250, 238). Owing to the divine alliance between Christ's redemptive acts and the agented work of the Holy Spirit (the work of the Holy Spirit is not apart from the work of Christ), all Christians are ushered into their eternal communion and fellowship with the triune God (Torrance 1995:156). That is, Christians are 'not saved or renewed by the activity of Christ without being united to him and partaking of him' through the Spirit (Torrance 1995:139). Through faith in Christ:

our human relations with God, far from being allowed to remain on a merely external basis, are embraced within the Trinitarian relations of God's own Being as Father, Son and Holy Spirit. (Torrance 1992:64)

Therefore, Christians are 'in union with God in and through Jesus Christ' in whom their 'human nature is not only saved, healed and renewed but lifted up to participate in the very light, life and love of the Holy Trinity' (Torrance 1992:66).

Given this, Torrance confronts us with the ontological inclusivity of all humankind in the vicarious humanity of Christ as the basis for the salvation of humanity (Kettler 1991:121). Once this established, we now turn to the exploration of the doctrine of Christ as a sinless representative of humanity using Torrance's conception as our guiding framework, however, in conversation with other scholars.

\section{Christ as a sinless representative of humanity}

Once the vicarious humanity of Christ is determined by the Greek patristic theological concepts, namely, the anhypostatic and enhypostatic union, the potential challenge which one can face is that if God in Christ identifies with sinful humankind in the incarnation, how can we escape the challenge of ending up with a sinful God in the incarnation? Cassidy (2008:193) poses this question of Torrance's incarnational Christological model: 'Once Torrance allows for the creation to constitute the divine nature, what is to prevent us from affirming a sinful God?' In Cassidy's (2008:193) view, this 'problem remains unanswered by Barthian theologians'. However, Cassidy seems to be misunderstanding Torrance's incarnational Christological theology. That is, he is inaccurately presenting Torrance's actual position, because the breadth of Torrance's writings addresses this question. Therefore, in answering Cassidy's challenge to the doctrine of the sinlessness of God in the incarnation, one should turn to Torrance's (2008:87-104) understanding of the supernatural sign of the virgin birth in his writings. Torrance employs the divine sign of the virgin birth to argue that the Son of God in the incarnation was not sinful; instead, he was a perfect, holy and righteous God, who assumed our sinful human nature and sanctified it for the sake of our redemption.

In Torrance's (1996:17-18; 1995:152-184; 2008:8-9, 119-120) view, the incarnation in its essence is God's gracious downward movement to within the bounds ${ }^{6}$ of space and 6.We are not making a case here for God's restriction within the finite world, only that he came to it. 
time in order to identify with all mankind for the sake of our redemption. Here, Torrance $(1995: 161 ; 2008: 94)$ contends that the Virgin Mary's conception of Jesus in her womb through the initiatory work of the Holy Spirit (Mt 1:18-25 and Lk 1:26-38) is key in arguing that the human nature in which Christ assumed in the incarnation was a sinless human nature. ${ }^{7}$ In Torrance's (2008:88, 101, 102-104) view, the doctrine of the virgin birth proves the insignificance of Joseph as the father of Jesus (though he is significant in his Davidic lineage, cf. Mt 1:1-16), because God the Spirit graciously took the initiative in the conception of Jesus in Mary's womb. ${ }^{8}$ In affirming this, Torrance is in agreement with Athanasius (1953:34), Barth (1956:190-196), O'Collins (1995:273-278) and Macleod (1998:225) on the theological significance of the faultless sign of the virgin birth in its connection to the sinlessness of the human nature of Christ. Athanasius (1953:34) indicates that the absence of the 'agency' of a 'human father' is vital in pointing out that Christ took upon 'spotless' or 'a pure' human flesh in the incarnation. Likewise, Barth $(1956: 191,192)$ explains that in the miraculous sign of Jesus' conception, 'sin is excluded and nullified'. However, the exclusion of male involvement in Mary's conception of Jesus in her womb does not designate the Virgin Mary as sinless. Here, one does well to concur with Barth's (1956) explanation that:

It is not as if virginity as a human possibility constitutes the point of connection for divine grace ... The sinful life of sex is excluded as the source of human existence of Jesus Christ, not because of the nature of sexual life, nor because of its sinfulness, but because every natural generation is the work of willing, achieving, creating, sovereign man. (p. 192)

However, in stating this, we are not inclining towards Macleod's (1998:229) conclusion that the human nature which Christ assumed at the incarnation was Adam's prefallen human nature. ${ }^{9}$ Even though the divine sign of Mary's conception nullifies the Adamic sin in Jesus Christ, Torrance (2008:63) and Barth (1956:155) are of the opinion that Jesus

\begin{abstract}
7.In Torrance's (2008:88) view, the gospels of Matthew and Luke are the only gospels
which 'bear witness to the virgin birth of Jesus', pointing to both the divinity and humanity of Christ. However, Torrance (2008:89) argues that Mark also implicitly mentions the virgin birth (the divine instigation of the birth of Christ). Mark alludes to the virgin birth in the Nazareth incident, where he referred to Jesus as the Son of Mary without any reference to Joseph as his Father (Torrance 2008:89). Matthew and Luke are interested in both the divinity and the humanity of Christ (the question in Matthew is whether Jesus was the carpenter's son, while in Luke the question is whether Jesus is the son of Mary); while Mark is interested in the divine origin of Christ, therefore, his failure to refer to Jesus as the son of Joseph was deliberate (Torrance 2008:88-89)
\end{abstract} 8. In this way, Torrance constantly maintains that the incarnation was the gracious act of God, in which the Virgin Mary was not in cooperation (synergism) with the Spirit 2008:101). This fits well wh Mary's rentich 2008:101). This fits well with Mary's response which was that of gratitude and 'humble submission and surrender to the will of God' (Luke 1:38) (Torrance 2008:101). However, the doctrine of the virgin birth does not only denote the divine origin of Christ, but it also has a couplet significance: it points us to the divine and human nature of Christ (Torrance 2008:98; cf. O'Collins 1995:273-278). By this, one means that the scriptural assertion that Jesus Christ was conceived in the womb of the Virgin Mary depicts Jesus' actual human existence (Torrance 2008:98 cf. O'Collins 1995:273-278). Here, Jesus Christ was not a mere human (docetic thinking) because he underwent all the '...embryonic processes of the womb just as other human beings' (Torrance 2008:98). That is to say, Torrance does not employ the supernatural sign of the virgin birth to downplay the true humanity of Christ instead, the virgin birth enables him to hold the existence of both the divine and human nature of Christ in the one person of the eternal Son of God.

9.Even Macleod cannot sustain this position when confronted by the question of whether or not Christ was capable of sinning. He has to opt for an alternative human nature to both a pre- and post-fallen human nature assumed by Christ Macleod (1998:229) concedes that because Adam 'could fall. ... With regards to the Last Adam, however, we must take a higher ground'.
Christ assumed Adam's human nature after the fall which was both unique and similar to our human nature. In other words, the virgin birth points us to the sinlessness of the human nature of Christ in relation to the Adamic sin or original sin from Genesis 3 (Macleod 1998:221-222). Torrance (1995) strongly contends that even though the human nature of Christ was Adam's human nature after the fall, the divine sign of the virgin birth points us to the actuality that:

when the holy Son of God took our sinful humanity upon himself, he did it in such a way that instead of sinning himself he brought his holiness to bear upon it so that it might be sanctified in him. (p. 184)

In using the anhypostatic and enhypostatic concepts, Torrance is in line with Sumner (2014:211-212) in that the immaculate sign of the virgin birth affirms that the human nature of Christ 'is anhypostatically fallen and enhypostatically sanctified' in the person of the divine Logos. That is to say, the human nature of Christ was sinless by its grounding in the divine person of the eternal Son of God in the incarnation. However, the sanctification of the human nature of Christ in the incarnation does not imply its divination or consumption by the deity of Christ; instead, it points to its (Christ's human nature) elevation by God's pure grace in the incarnation (Torrance 1995:161, 2008:9).

That is, in the incarnation, Jesus' human nature was both similar and dissimilar with Adam's human nature after the fall (Torrance 2008:61). Torrance (2008:61, cf. 78) captures the symmetry of the human nature of Christ with Adam's human nature after the fall in this way:

There can be no doubt that the New Testament speaks of the flesh of Jesus as the concrete form of our human nature marked by Adam's fall, the human nature which seen from the cross is at enmity with God and needs to be reconciled ... In becoming flesh the Word penetrated into hostile territory, into our human alienation and estrangement from God.

Nevertheless, owing to the immaculate sign of Jesus' birth, there is a robust continuity and discontinuity between Jesus Christ's human nature and Adam's sinful human nature (Torrance 2008:94). Here, one should approve of Leftow (2011:44) and Cole's (2013:142) conclusions about the uniqueness of the human nature of Christ (owing to the divine sign of the virgin birth) and the likeness of the human nature of Christ with our human nature. Leftow (2011:44) concludes that in the incarnation, God the Son was a unique 'human being', but he was also truly 'human as the rest of us'. With regard to Christ's assumption of our human nature, Cole (2013:142) expands that 'Christ did not become incarnate in some unreal unfallen creation, but in this actual fallen one'. In agreement with Leftow and Cole, Sumner (2014:207, our emphasis) adds that the human nature of Christ is identical with our human nature 'because it is our nature which was assumed', and Christ's human nature is unique because his human nature 'was elevated by virtue of its direct union with God' in the divine mystery of the incarnation. Here, the sanctification of the human nature of Christ was vital because it enables the inclusion of the sinful human nature of Christ 
in 'the identity of God the Son', so that his blood can cleanse the sins of all humankind, thereby, bringing them back into an eternal union and fellowship with God (Sumner 2014:207).

In bringing Christology and soteriology to bear on this matter, Torrance (2008:63) coincides with Dunn's (1989:112) assertion that 'Jesus the sinless one, became wholly one with the sinner/Adam, so that those who became one with the risen Christ ... might share in the righteousness of God'. This is because:

Jesus does not do in the flesh of sin what we do, namely, sin, but it also means that by remaining holy and sinless in our flesh, he condemned sin in the flesh he assumed and judged it by his very sinlessness. (Torrance 2008:63)

In substantiating this, Torrance (2008:92-94) briefly discusses the treatment of Jesus Christ as the new or last Adam as an indication of the divine origin of Christ, which qualifies the sinlessness of Jesus' humanity (Rm 5:12-21 and 1 Cor 15:23). That is, Jesus Christ the God-man, who fully identifies with us in all aspects of our lives (except in our sin), could undo Adam's sin. He (Jesus Christ) lived an obedient life unto God the Father to the point of death on the cross, therefore, redeeming all humankind from their oppression of sin.

Once the aforementioned discussion is accepted, one can argue that Torrance's incarnational Christological model argues for the reality of the sinlessness of the assumed human nature of Christ from a broad framework of scripture. That is, with the doctrine of $\sin (\mathrm{Gn} 1-3)$ as the backdrop in his mind, Torrance (2008:63-73; cf. Macleod 1998: 221-230) is aware that Jesus fulfils the role of an unblemished or perfect lamb of God (Jn 1:29), which knows no sin to be offered before God as a once and for all sacrifice for the sins of all mankind (2 Cor 5:21, cf. Heb 10:1-8). One should agree with Torrance because the gospels present Christ as sinless (he did not commit sin) in the midst of various temptations (cf. Mt 4:1-11, Lk 4:1-13 \& Mk 1:12-13). No one could accuse him of being guilty of sin (Jn 8:46) (Macleod 1998:221). This corresponds well with the overarching notion that Jesus in his entire life never asked God the Father for the forgiveness of sins (Macleod 1998:221). Instead, he taught his disciples to ask God the Father to forgive their sins whenever they pray to him (Lk 11:1-13 \& Mt 6:9-13) (Macleod 1998:221). In light of this, the apostle Paul (in 2 Cor 5:21; cf. Gl 3:13) can confidently affirm Jesus Christ as the sinless man, who bears our sins at the cross, so that 'in him we might become the righteousness of God'. That is, as a sinless God-man, Jesus Christ can act as a once and for all perfect sacrifice for the atonement of our sins, hence, leading us back into eternal communion and fellowship with the triune God (Torrance 2008:73).

Nonetheless, the aspect of the sinlessness of Christ can mistakenly lead one to contend that in the incarnation, Jesus Christ did not fully identify himself with true humanity, because human nature is sinful. That is, Jesus Christ was to fully identify with us in our sinful human nature in order to save us from the depth of our human existence. In other words, one would be incorrect in advocating that Jesus Christ was to be utterly righteous and utterly sinful for the adequate salvation of sinful humanity to take place. In response to this misconception, it can be asked: Does Christ's full identification with humanity mean that he has to participate in our sinful or fallen human nature? The aforesaid misconception answers 'yes' to this question. Now, if he was sinful, how could he save us from our sins, or how could God present him as a once and for all perfect sacrifice that pays the price for the sins of humankind? With that in mind, the notion that Jesus Christ was to fully identify with us in our sinful human nature by participating in sin (in order to save us from the depth of our human existence) tends to downplay the actuality that by nature, God is holy and righteous. Therefore, he stands in opposition to sin. Torrance (2008) summarises it in this way:

Thus we must say that while he, the holy Son of God, became what we are, he became what we are in a different way from us. We become what we are and continue to become what we are as sinners ... Christ the Word did not sin. He did not become flesh of our flesh in a sinful way, by sinning in the flesh. If God the Word became flesh, God the Word is the subject of the incarnation, and how could God sin? How could God deny God, divest himself of his holiness and purity? Thus his taking of our flesh of sin was a sinless action. (p. 63)

Barth (1956) supports Torrance's earlier observation as he affirms that:

In becoming the same as we are, the Son of God is the same in quite a different way from us; in other words, in our human being what we do is omitted, what we omit is done. The man would not be God's revelation to us, God's reconciliation with us, if he were not, as true man, the true unchangeable, perfect God himself. He is the true God because and so far as it has pleased the true God to adopt the true being of man. But this is the expression of a claim upon this being, a sanctification and blessing of this being, which excludes sin. In it God himself is the subject. How can God sin, deny himself to himself, be against himself as God? (p. 155)

In agreement with the preceding point, Torrance (2008:73) and Macleod (1998:225) highlight that true humanity is not measured by one's participation in sin. In Torrance's (2008:73) observation, 'the commission of $\sin$ is no attribute of true humanity but the attribute of inhumanity'. Therefore, for our understanding of true humanity, we look up to Jesus Christ as the benchmark of true human existence. Jesus Christ does not need to conform to our fallen human living. True humanity was originally created by God without being participative in sin (Macleod 1998:225). In this way, the discontinuity between the human nature of Jesus Christ and our sinful human nature is that Jesus Christ was a sinless human being (true human existence), who has a continuity with us as a human being in our likeness (except in sin) and lived in the depth of the sinful structures of our human existence without giving in to the temptations of this fallen world. Barth (1956) explains that Jesus Christ:

[a]ssumes our human existence, assumes flesh i.e. He exists in the state and position, amid the conditions, under the curse and punishment of sinful man. He exists in the place where we are, in all remoteness not merely of the creature from the Creator, but of the sinful creature from the Holy Creator. (p. 155) 
Nevertheless, in affirming the sinlessness of the human nature of Christ we are not inclining towards $\mathrm{O}^{\prime}$ Collins (1995:271) and Macleod's (1998:229-230) conclusion that Jesus Christ was incapable of sinning. Instead, we are supporting Crisp's (2009:122-136) argument that Jesus Christ's human nature was capable of sinning, especially by his philosophical examination of Jesus' temptation narratives in the gospels. This is because being sinful and capable of sinning are two different things. Crisp contends that Jesus had the capacity to commit sin, because in real nature, a temptation implies one's 'capacity to be tempted and feel the "pull" of temptation' (Crisp 2009:136). In this way, if Jesus' temptations were true, it follows that he (Jesus) was capable of being sinful. Here, Crisp's understanding seems to have a biblical license because Christ in our likeness was tempted like all of us, yet he lived without $\sin$ (Heb 4:15). Thus, Jesus Christ can act as our faithful and merciful high priest, who is able to sympathise with us in all our weaknesses because he was like us in all aspects, except in $\sin$ (Heb 4:15). Even if one argues that Christ assumed Adam's pre-fallen human nature, it does not result that Christ was therefore incapable of sin. An understanding of Jesus Christ as capable of sinning (though he did not $\sin$ ) is in consistency with Adam's prefallen human nature, which was created by God in a sinless state yet was capable of committing sin. That is, like Adam's pre-fallen human nature, Christ's human nature was sinless but capable of committing sin. However, instead of sinning, Christ lived an obedient life unto the Father, so that in his saving work, he can both recreate and restore us from the bondage of corruption.

Having said this, however, one must conclude that the sinlessness of Jesus Christ in the incarnation is still a mystery to us. At this overlapping of ages, 'sin limits our intelligence and its functioning further, hampering our understanding especially insight into spiritual matters' (Erickson 1991:547). That is, because of the human pandemic of sin, our understanding of the incarnation is limited; we can only have a partial degree of knowledge concerning the incarnational mystery of God the Son. However, the prevailing truth is that:

within this human-inhuman existence of Adam, Jesus Christ comes as the Son of God, the Son of man as Jesus calls himself, to live out a truly obedient and filial, that is a truly human life, in perfect and unbroken union with God the Father. In all of that Jesus Christ is the last Adam, the one who ... brings to an end the bondage of Adam's sin, breaks its power and opens up a new and living way to God. (Torrance 2008:73)

\section{The challenge in engaging African scholars' understanding of the doctrine of the sinlessness of Christ}

Nevertheless, the challenge one encounters in trying to engage African scholars in establishing the biblical theological foundational status of the doctrine of Christ's incarnation and Christ as a sinless representative of humanity is that many African scholars (i.e. Bediako 2004:20-33; Bujo 1992:7591; Nyamiti 2005:23-146) neither explore nor develop the theological foundational status of the doctrines of Christ's incarnation or Christ as a sinless representative of humanity.
Rather they assume the validity of the Evangelical Christian doctrines of the incarnation and the sinlessness of Christ established by the Nicaea (in AD 325) and Chalcedon (in AD 351) and then apply these doctrines to the traditional African worldview of ancestral veneration by juxtaposing Christ with the ancestors. Thus, these theologians do not have a comprehensive treatment of the doctrines of Christ's incarnation or Christ as a sinless representative of humanity. In this way, the theology of many African scholars in this regard does not demonstrate to us how the various tenets of the Christian doctrine of Christ's incarnation, as well as Christ as the sinless representative of humanity, relate to their theological endeavours. Once this is granted, it is difficult for us to engage African theologians' understanding of Christ's incarnation and Christ as a sinless representative of humanity in relationship to their theology.

For example, Bujo (1992:75, 75-91) in his monograph that stands as his foundation of African theology in its social context states that the person of Jesus Christ and the community of the church are two of the fundamentals of Christian faith'. Afterwards, Bujo (1992:87-108) treated Christ as the Proto-Ancestor as a model of African morality without demonstrating the various tenets that are brought together to configure the person of Jesus Christ as fundamental in Christian faith. Conclusions adopted from the various church councils are simply applied to Christian issues such as ancestral veneration without demonstrating the foundational status of his theology from Scripture itself. Likewise, Nyamiti (2005:23) agrees with the authors that the identification of Christ as an African ancestor 'can rightly made only when there is sufficient basis in the sources of Christian theology (Bible and Church tradition) to justify it'. Nevertheless, without establishing a biblical theological foundational status of his theology from Scripture, Nyamiti (2005:65-146) simply applies the evangelical doctrine of the Trinity to his ancestral discussions, which results to his treatment of Christ as a Brother-Ancestor. As well, Bediako (2004:20-33) followed the same trappings when his discussion of Christ as the Supreme ancestor simply deals with the epistle of Hebrews at the expense of the wider scope of scripture. In his discussion, there seems to be an inadequate establishment of the basis of Christ as a Supreme Ancestor because his focus was to underscore the significance of the epistle of Hebrews in the African context of ancestral veneration. It is important to acknowledge that these African theologians are trying to deal with pertinent African contextual issues; however, it is difficult to engage with them when one's enterprise is the demonstration of the theological foundational status of doctrines such as the incarnation of Christ, as well as Christ as a sinless representative of humanity.

Given this, one should not be surprised to see the absence of African theologians in the above discussions concerning the biblical-theological foundational status of the doctrines of Christ's incarnation and Christ as a sinless representation of humanity. This is because in view of the undertaken 
discussions, many African theologians do not engage with the issues from that particular manner. Instead, they are more focused with the application of doctrinal concepts into African contextual issues without underscoring the biblicaltheological foundational status of such doctrines.

\section{Juxtaposition of Christ and traditional African ancestors and the consequent implications to the spiritual security of African Christians}

Emerging from the above discussions is that Jesus Christ is the sinless representative of humanity who takes his sinless human characteristics into the other world, while the traditional African ancestors are sinful human beings who take with them their human characteristics into the other world, i.e. the world of spiritual powers. Given this unique distinction between Christ and the natural ancestors, we argue that the ancestors pose spiritual insecurity to Africans because they are deceased human beings who take into the afterlife their negative human characteristics that include 'jealous, unreliable, tyrannical or even just plain evil' (Ashforth 2005:209).

The above-mentioned qualitative distinction between Christ and the natural ancestors confronts African Christians with the truth that Jesus Christ is our sinless saviour, who has taken his sinless human characteristics into the afterlife; therefore, he is able to protect African Christians from the spiritual powers of darkness without posing insecurity to them. The understanding that Christ carried his sinless human qualities into the afterlife is intrinsic within the affirmation that the death, resurrection and ascension of Christ (cf. Ac 1:6-11 \& Lk 24:50-53) were not an artificial historical event in the history of Christianity. For instance, the ascension of Christ is the entering of the uninterrupted or eternal hypostatic union between God and humanity ${ }^{10}$ into the eternal place of God in heaven (Torrance 2009:287-289). This eternal union between God and man commenced at the incarnational mystery, and is then realised by Christians in time as they believe in the redemptive acts of Christ. In other words, by the ascension, we mean that our fully God-man, Jesus Christ, had died and resurrected in his permanent union with man and ascended to heaven in which he is seated at the right hand of God the Father and is directing all history from the 'mercy seat of God' (Torrance 2009:271). This demonstrates that Jesus Christ died, resurrected and

10. Here, Torrance has foreshadowed Farrow's (1999:13) contention against people who misconceive the humanity of Christ when it comes to the doctrine of ascension. One of these misconceptions is to take away Christ's humanity, maybe through divinising the ascended humanity of Christ. This has huge negative implications for Christians, because believers may tend to think of themselves as divinised in Christ, therefore, whatever they (believers) do is right. Above all, the aspect of the divinisation of the humanity of Christ may be used to validate the aspect of the divinisation of the humanity of Christ may be used to validate the worship of the saints in some Roman Catholic churches. Noticeably, the divinisation of the humanity of Christ seems to have some parallels with traditional African beliefs of ancestors - as the mediators between God and man, because they have aquired the supernatural power. Given these highlighted dangers, one should agree with Farrow (1999:33-34) that the upholding of Christ's true humanity in ascension is vital in our understanding of Christ as our priestly mediator who 'sat down in the presence of God as our Melchizedekian priestly-king' and sympathises with us in all our weaknesses. ascended into heaven as a true sinless representative of humanity in whom we have to trust confidently for our spiritual security.

In avowing that Jesus Christ died, resurrected and ascended as true God-man, we are denying any disowning of the true union between God and humanity in one person of the divine Logos, the eternal Son of God. Also, we are denying an elusive understanding of Jesus Christ as an ideal God or mere human being (docetism) (Torrance 1995:113; 2008:9, 98). Furthermore, we are ultimately rejecting the misconception of Jesus Christ as a true man, whom God (out of his favour) has adopted at a particular point to be in a special relationship with himself (God) (Torrance 2009:452). The former (docetism) denies the true humanity of Christ and the latter (adoptionism) denies the 'pre-existence' of Christ (Erickson 1991:532).

In moving from the doctrinal articulation of Jesus Christ as the true sinless God-human being (who died, resurrected and ascended into the heavenly realm in his uninterrupted sinless union between God and human beings), we are of the opinion that the contrast between Jesus Christ and the traditional African ancestors who are in harmony with the sinful regime of Adam has to be emphasised in a significant way. That is, given the natural ancestors' cooperate identity in the sinful Adam (cf. Gn 3 and Rm 5:12-21), it can be argued that the traditional African ancestors cannot but have flawed, unpredictable influence for good and bad on their descendants which keeps Africans in terror. With this granted, the good news for African Christians is that our sinless saviour, Jesus Christ, is the true sinless representative of humanity (who died, resurrected and ascended into heaven) who is able to protect them from the invisible powers without any possibility of unpredictable negative influence to those united to him by faith, namely, Christians.

This above-mentioned understanding should make African Christians to be confident and depend (rely) more on Christ to meet their African contextual needs. That is, Christians should know that their saviour, Jesus Christ, is faultless and reliable. Contrary to the natural ancestors, Christ has demonstrated his reliableness by the perfect life he lived in his entire earthly life in the midst of many and different adversaries, temptations and challenges. For instance, Christ battled against the evil forces in his earthly ministry. However, regardless of all the attempts from the powers of darkness to terminate the unbreakable union between his divine and human nature, Christ lived an obedient life to the Father until the point of death at the cross (Bediako 2004:29; Torrance 2009:247-256). In line with Christ's obedient life to the Father, the resurrection stands as the ultimate bridging of sinful humanity from death to life (cf. Heb 2:5-18) in the midst of the evil forces' endeavour to reverse the salvific role of the incarnated Son of God. That is, it is at the resurrection that the decisive victory of Christ over the spiritual forces of darkness is overwhelmingly claimed, once and for all, but this should be apprehended in 
view of the overlapping of ages (Torrance 2009:247-256). At this juncture, we are moving to the establishment that through faith in Jesus Christ, African Christians should be confident that they are putting their trust in a saviour who is faithful and reliable in all circumstances as he demonstrated it by his perfect earthly life that led to his overwhelming victory over sin and its consequences for humankind.

Moreover, in view of the misconception of the traditional African world view that perceives natural ancestors as the intermediaries between God and man, we ground the qualitative distinction between Christ and natural ancestors within the evangelical doctrine of the Trinity that affirms that Jesus Christ is of one being with God the Father. We are grounding our theology within the Christian doctrine of the Trinity so that African Christians can know that through faith in the God-human being, Jesus Christ, they are in union with a sinless saviour, who is qualified to minister faithfully and mercifully the things of God to man and man to God without fault (Heb 1 \& 2). Jesus Christ is superior to the traditional African ancestors because he is both close to human beings as true human and close to God than natural ancestors because he is of one existence with God the Father (cf. Pobee 1979:94). In this way, there is no aspect of both human and God that are alien to him, that is Just like Adam, Jesus Christ came into existence as a true sinless human beings, who was capable of sinning but did not commit sin (Crisp 2009:136; Torrance 2008:73). In other words, because Jesus Christ was a human being in our likeness (except in sin), who lived in the depth of the sinful structures of our human existence without giving in to the temptations of this fallen world, African Christians are assured that they have a superior merciful and faithful mediator who sympathises with them in their African contextual challenges. In this way, African Christians can now solely believe in Jesus Christ, who supersedes their natural ancestors rooted in the sinful regime of Adam (Barth 1956:155; Torrance 2008:63).

In substantiation, the reality of the ascended Christ as a sinless God-man should enable African Christians to have certain confidence in their security in Christ. That is, in contrast to the view of natural ancestors as the mediators between God and man in traditional African religion, we argue that the sinlessness of the God-man, Jesus Christ should be taken by African Christians as a guarantee that they can fully trust him (Jesus Christ) as their flawless mediator and saviour who supersedes the natural ancestral mediators that people may claim for their clans, families, tribes and nations (Heb 2; Bediako 2004:28). In concurrence with Bediako (2004), this is because the divine-human nature of Christ:

Enabled him to share the human predicament and so qualified him to act for humanity. His divine origin ensures that he is able to mediate between human community and the divine realm in a way no human priest can. As himself God-man, Jesus bridges the gulf between the Holy God and sinful humanity, achieving for humanity the harmonious fellowship with God that all human priestly mediations only approximate. (p. 29)

\section{Healing and coping intersection with spiritual insecurity within pastoral guidance space - Interplay of Christology (Christ's sinlessness) and practical life}

Thus far, the doctrine of Christ's sinlessness and humanity's union with Christ has been presented. While such doctrine could be viewed as a cognitive process, it provides some concrete practical pastoral guideline pointers for healing and coping with life in the context of African ancestors. To decipher the pastoral guidelines, it is important to proceed from an understanding of the notion of healing and coping within Christianity.

Healing and coping within pastoral ministry is connected to salvation. De Gruchy (1989:39) maintained that healing cannot be separated from the notion of salvation. Pastoral care as a healing ministry is grounded in Jesus Christ, the very God himself. Bowden (2005:1112) added that our understanding of sickness and healing in the Christian tradition should be rooted in Jesus' ministry. Thus, in pastoral care, Jesus and salvation are central in the pursuit of healing. 'The story of salvation is linked to the story of parishioners' struggle, agony and suffering' (Magezi 2007:657). Hunter (1995:18) usefully drew a link between healing and pastoral care ministry by stating that pastoral care and counselling are conceived as a healing art, and the field as a whole has taken health and healing as its primary metaphor for a personal caring ministry. Louw (2008:11) added that pastoral care is about healing and cura vitae [the healing of life]. Healing is about being connected to Christ (soteriology), which revitalises life and makes it meaningful and purposeful (as a pneumatological being). This way pastoral care is connected to Christology, salvation and healing. Louw (2014:35) clarifies that the interplay of these concepts indicates the resources that should be invoked within the art of Christian healing during life's existential challenges. Therefore, in engaging in African Christian healing ministry, one should understand that the salvation by God in and through Jesus Christ encompasses both physical and spiritual dimensions. Indeed, there is no need to limit Christ's salvation to sin or the soul as some early Western missionaries did during the early missionaries' era of Christianity in Africa (Aho Ekue 2005:104; Mbiti 1989:158-159).

The above understanding of healing and consequent coping with life makes Christ central. The distinction of Christ's attributes such as sinlessness, loving, caring and forgiving compared to sinful people who carry on with their sinful nature to the next phase of their existence as ancestors clearly makes Christ a trusted and dependable figure in life over ancestors. By virtue of knowing that nothing is held against me by Christ because of his grace and achieved salvation gives a sense of peace and confidence compared to ancestors who require appeasement and towing their line in order for things to go well. Being God, Christ has no evil or grudge 
with people. The point being made here is that, presented with a choice between the two (ancestors and Christ), it is obvious that Christ stands as an incomparable figure to be embraced. He ushers peace, comfort and positivity.

Furthermore, Christ decisively demonstrated his power over any evil or any spiritual threats through victory over death on the cross. The resurrection demonstrated the decisive victory of Christ over the spiritual forces of darkness. Therefore, by placing their hope and trust in Christ, African people should be confident that they are putting their trust in a saviour who is faithful and reliable in all circumstances. This, then, should stir practical hope. Also, by being united with Christ who identifies with humanity, Christians are grafted to a saviour, who is qualified to minister faithfully and mercifully (Heb 1 \& 2 ) to them. This means Jesus Christ is close to humanity as a true human being and closer to God than natural ancestors. In this way, there is no aspect of both humanity and God that are alien to him. This reality makes Christ a dependable person. Therefore, as indicated above, African Christians are assured that they have a superior, merciful and faithful Christ who sympathises with them in their African contextual challenges. African Christians can hold on to Jesus Christ with hope and a sense of security as he (Christ) supersedes the natural ancestors who are capricious.

\section{Conclusion}

The discussion above brings one to the conclusion that many African people are living in spiritual insecurity, derived from their fundamental, traditional belief in the interrelationship between the physical and metaphysical worlds. Africans believe that the metaphysical world is populated by various spiritual powers (i.e. Supreme Being, lesser spiritual divinities, spirits and ancestors) that exert negative and positive influence to their lives. The traditional African 'concept of reality and destiny [is] deeply rooted in the spirit world, for the activities and actions of spirit beings are believed to govern social and spiritual phenomena' (Turaki 2006:26). Within the traditional African world view of spiritual powers, the ancestral veneration is at the centre of traditional African religion and spirituality. This is because the ancestors are said to have acquired a supernatural power, which enables them to offer diagnoses and solutions to the challenges of African people that emanates from the spiritual powers. Hence, the ancestors promote or hinder African Christians' reliance on Christ. However, the problem which has arisen in ancestral belief is that, although the ancestors are respected, the living people nevertheless fear them because they pose terror to their descendants. This is because the ancestors still behave like humans. They have carried their sinful human characteristics to the afterlife. The ancestors can either bless or harm their descendants depending on the state of the volatile relationship between humanity and these spiritual divinities.

Given this, we argued that the fundamental response to the spiritual insecurity of African Christians is their proper understanding of Christ as a sinless representative of humanity. In establishing the biblical-theological foundational status of Christ as a sinless representative of humanity (using Torrance's conception as the controlling framework but in conversation with other theologians), we juxtaposed Christ's sinlessness and the sinfulness of natural ancestors. In this juxtaposition, we contend that because of their sinful human characteristics, the traditional African ancestors cannot but have flawed and unpredictable influence for good and bad on their descendants, which keeps Africans in terror. Conversely, Jesus Christ is the sinless representative of humanity who is able to protect African Christians from the invisible powers without any possibility of unpredictable negative influence to those united to him by faith, namely, Christians. Therefore, this approach pays close attention to the factors and mindset that sustain adherents to ancestral veneration and assess them through a thorough lens of appropriate and constructive Christology focusing on Christ's sinlessness as an exemplary doctrine.

\section{Acknowledgements Competing interests}

The author declares that he has no financial or personal relationships which may have inappropriately influenced him in writing this article.

\section{Authors' contributions}

V.M. and C.M. equally contributed to the research and writing of this article.

\section{References}

Aho Ekue, A.A., 2005, 'Troubled but not destroyed. The Development of African theologies and the paradigm of theology of reconstruction', in K. Koschorke (ed.), African identities and World Christianity in the twentieth century, pp. 101-102, Harrassowitz Verlag, Wiesbaden.

Ashforth, A., 2005, Witchcraft, violence, and democracy in South Africa, University of Chicago Press, Chicago, IL.

Athanasius, 1953, St Athanasius on the incarnation, 2nd edn., Mowbray, London.

Banda, C., 2005, 'The sufficiency of Christ in Africa: As Christological challenge from African traditional religion', MA dissertation, University of South Africa, Pretoria, South Africa.

Barth, K., 1956, Christ and Adam - Man and humanity in Romans 5, Oliver \& Boyd, Edinburgh.

Barth, K., 1958, Church dogmatics: The doctrine of reconciliation. IV. 1, transl. G.W. Bromiley \& T.F. Torrance, T. \& T. Clark, Edinburgh.

Barth, K., 1960, Church dogmatics. The doctrine of the word of God. I. 1, transl. G.T. Thomson, T. \& T. Clark, Edinburgh.

Bediako, K., 2004, Jesus and the gospel in Africa: History and experience, Orbis Book, New York.

Benn, C., 2002, 'The influence of cultural and religious frameworks on the future course of the HIV/AIDS pandemic', Journal of Theology for Southern Africa 113, 3-18.

Bowden, J., 2005, Christianity: The Complete Guide, Continuum, London.

Bujo, B., 1992, African theology in its social context, Orbis Books, Maryknoll, NY.

Calvin, J., 1960, Institutes of the Christian religion 1, J.T. McNeill (ed.), Westminster Press, Philadelphia, PA.

Cassidy, J.J., 2008, 'T. F. Torrance's realistic soteriological objectivism and the elimination of dualisms: Union with Christ in current perspective', Mid-America Journal of Theology 19, 165-194.

Cole, G.A., 2013, The God who became human: A biblical theology of incarnation, Inter Varsity Press, Downers Grove, IL.

Crisp, O.D., 2009, God incarnate: Explorations in Christology, T \& T Clark International, London, NY.

De Gruchy, J., 1989, 'Salvation as healing and humanization', in T.A. Hart \& D.P. Thimell (eds.), Christ in our place: The humanity of God in Christ for the reconciliation of the world, pp. 32-47, Paternoster, Exeter. 
Dunn, J., 1989, Christology in the making: A New Testament inquiry into the origins of the incarnation, 2nd edn., William B. Eerdmans, Grand Rapids, MI.

Dyrness, W.A., 1990, Learning about theology from the third world, Zondervan, Grand Rapids, MI.

Erickson, M.J., 1991, The word became flesh: A contemporary Incarnational Christology, Bakers Books, Grand Rapids, MI.

Farrow, D., 1999, Ascension and Ecclesia: On the significance of the doctrine of the Ascension for Ecclesiology and Christian Cosmology, William B. Eerdmans, Grand Rapids, MI.

Hesselgrave, D.J., 1991, Communicating Christ cross culturally: An introduction to missionary communication, Zondervan, Grand Rapids, MI.

Hood, R.E., 1990, Must God remain Greek? Afro cultures and God-Talk, Fortress Press, Minneapolis, MN.

Hunter, R.J., 1995, 'The therapeutic tradition of pastoral care and counselling', in R.J. Hunter (ed.), Pastoral care and social conflict, pp. 17-31, Abingdon, Nashville, TN.

Igba, J., 2013, 'Ancestor Christology and Jesus' identity: A study based in the epistle to the Hebrews', MA dissertation, North-West University, North-West.

Imasogie, O., 1983, Guidelines for Christian theology in Africa, Africa Christian Press, Achimota.

Ishola, A.S., 2002, 'Christianity Vis-à-Vis traditional religions', Southwestern Journal of Theology 44(2), 44-60.

Kettler, C.D., 1991, The vicarious humanity of Christ and the reality of salvation, Wipf \& Stock, Eugene, $\mathrm{OR}$

Kok, D.B., 2005, Christianity and African Traditional Religion: Two realities of a different kind, Kachere series, Zomba.

Kraft, C.H., 1999, 'Culture, world-view and contextualization', in R.D. Winter \& S.C. Hawthorne (eds.), Perspectives on the world Christian movement, 3rd edn., pp. 384-391, William Carey Libray, California, CA

Kunhiyop, S.W., 2012, African Christian theology, Zondervan, Grand Rapids, MI.

Leftow, B., 2011, 'The humanity of Christ', in A. Marmodoro \& J. Hill (eds.), The metaphysics of the incarnation, pp. 20-44, Oxford University Press, Oxford.

Light, V.E., 2010, The Evangelical Church in Africa: Towards a model for Christian discipleship, MTh dissertation, South African Theological Seminary, Johannesburg.

Louw, D.J., 2002, 'A practical theological ecclesiological of relocalisation and globalisation from below: Towards a viable African Renaissance', Journal of Theology for Southern Africa 112, 69-87.

Louw, D.J. 2008, Cura Vitae: IIIness and the healing of life in pastoral care and counselling, Lux Verbi, Cape Town.

Louw, D.J., 2014, Wholeness in hope care on nurturing the beauty of the Human soul in spiritual healing, LIT, Wien.

Lugira, A.M., 2009, World religions: African traditional religion, 3rd edn., Chelsea House Publishers, New York.

Macleod, D., 1998, The person of Christ: Contours of Christian theology, Inter-Varsity Press, Leicester.

Magezi, V., 2007, Pastoral counselling: Towards a diagnostic and interpretational approach in Africa, Die Skriflig 41(4), 655-672.

Mashau, D.T., 2009, 'A reformed missional perspective on secularism and pluralism in Africa: Their impact on African Christianity and the revival of traditional religion', Calvin Theological Journal 44, 108-126.

Mbiti, J., 1989, African religions and philosophy, Heinemann, London.
Michael, M., 2013, Christian theology and African traditions, Lutterworth Press, Cambridge.

Moltmann, J., 1974, The crucified God, SCM Press Ltd, London.

Mwaura, P.N., 2006, 'The anthropological dimension of a patient's treatment: A response to Prof. Bernard Ugeux', International Review of Mission 95(376/377), 136-142. https://doi.org/10.1111/j.1758-6631.2006.tb00548.x

Nakah, V., 2006, 'Evangelical Christianity and African culture', PhD thesis, University of Stellenbosch, Stellenbosch.

Naugle, D.K., 2002, Worldview: The history of a concept, W.B. Eerdmans Publishing Company, Grand Rapids, MI.

Nurnberger, K., 2007, The living dead and the living God: Christ and the ancestors in changing Africa, C B Powell Bible Centre, Pretoria.

Nyamiti, C., 2005, Jesus Christ, the ancestor of humankind: Methodological and trinitarian foundations, CUEA Publications, Nairobi.

Nyamiti, C., 2006, Studies in African Christian theology, Vol 2. Jesus Christ, the Ancestor of Humankind: An essay on African Christianity, CUEA Publications, Nairobi.

O'Collins, G.J., 1995, Christology: A biblical, historical and systematic study of Jesus, Oxford Press, Oxford.

Okorocha, C.C., 1994, 'The meaning of salvation: An African perspective', in W.A. Dyrness (Gen. ed.), Emerging voices in global Christian theology, Zondervan, Grand Rapids, MI.

Oladosu, O.A., 2012, 'Ancestral veneration in the religious expression of the indigenous Aladura Churches', Ogbomoso Journal of Theology XVII(2), 159-171.

Pobee, J., 1979, Toward an African theology, Abingdon, Nashville, TN.

Reed, R. \& Mtukwa, G., 2010, 'Christ our ancestor: African Christology and the danger of contextualization', Wesleyan Theological Journal 45(1), 144-163.

Salala, C. 1998, 'The world of the spirits: Basukuma traditional religion and biblical Christianity', in S. Ngewa, M. Shaw \& T. Tienou (eds.), Issues in African theology, pp. 133-138, East African Education Publishers, Nairobi.

Sogolo, G.S., 1991, 'The concept of cause in African though t', in P.H. Cotzee \& A.P.J. Roux (eds.), Philosophy from Africa: A text with readings, pp. 177-185, Oxford University Press, Oxford.

Sumner, D.O., 2014, 'Fallenness and anhypostasis: A way forward in the debate over Christ's humanity', Scottish Journal of Theology 62(2), 195-212. https://doi. org/10.1017/S0036930614000064

Torrance, T.F., 1992, The mediation of Christ, W.B. Eerdmans Publishing Company, Grand Rapids, MI.

Torrance, T.F., 1995, The Trinitarian faith, T \& T Clark, Edinburgh.

Torrance, T.F., 1996, The Christian doctrine of God: One being three persons, T \& T Clark, Edinburgh.

Torrance, T.F., 2008, Incarnation: The person and life of Christ, IVP Academic, Downers Grove, IL.

Torrance, T.F., 2009, Atonement: The person and work of Christ, IVP Academic Downers Grove, IL.

Triebel, J., 2002, 'Living together with the ancestors: Ancestor veneration in Africa as a challenge for missiology', Missiology: An International Review XXX(2), 187-197.

Turaki, Y., 2006, Foundations of African traditional religion and world-view, Word Alive Publishers, Nairobi.

Westerlund, D., 2006, African indigenous religions and disease causation from spiritual beings to living humans, Brill, Leiden.

Wethmar, C., 2006, 'Conceptualization of evil in African Christian theology', Acto Theologica 1, 249-257. 